\title{
Attitudes Towards Functional Foods Scale: Psychometric Proprieties and Adaptation for Use Among Adolescents
}

\author{
Escala de Atitudes Face a Alimentos Funcionais: \\ Propriedades Psicométricas e Adaptação para Uso em \\ Adolescentes
}

\author{
Leandro OLIVEIRA ${ }^{1}$, Rui POÍNHOS², Francisco SOUSA ${ }^{3,4}$ \\ Acta Med Port 2019 Apr;32(4):266-271 - https://doi.org/10.20344/amp.9284
}

\section{ABSTRACT}

Introduction: Functional foods are those that promote health and well-being and/or decrease the risk of certain chronic diseases. It is known that young people' knowledge about functional foods is low. The aim of this study is to assess the psychometric proprieties of the "Attitudes towards Functional Foods Scale" in a sample of adolescents and, based on that analysis, adapting the scale for its use among this population group.

Material and Methods: After a pre-test, the scale was applied to 340 students attending the $3^{\text {rd }}$ cycle of basic education in Terceira island (Azores, Portugal), whose ages ranged between 11 and 19 years (mean $=14.0$, standard deviation $=1.2$ ). We analyzed the scale's internal consistency and construct validity.

Results: The study of the psychometric proprieties led to the exclusion of one item. Cronbach's alpha $(\alpha=0.876)$ showed a good internal consistency of the scale, and factor analysis revealed that, as the original (adults) version, it presents an unifactorial structure. Discussion: The scale showed to be an instrument easy and quick to apply among adolescents. We emphasize that its application should be preceded by the clarification on the concept of functional foods in order to ensure the adequacy of the answers.

Conclusion: This study has demonstrated the adequacy of the Attitudes Towards Functional Foods Scale to assess Portuguese adolescents' perception regarding functional foods, highlighting the need of using its adapted version.

Keywords: Adolescent; Azores; Functional Food; Life Style; Portugal; Psychometrics; Surveys and Questionnaires

\section{RESUMO}

Introdução: Os alimentos funcionais são aqueles que promovem a saúde e o bem-estar e/ou reduzem o risco de determinadas doenças crónicas. Sabe-se que o conhecimento dos jovens sobre alimentos funcionais é baixo. Este estudo visou estudar as propriedades psicométricas da Escala de Atitudes face a Alimentos Funcionais numa amostra de adolescentes e, com base nesse estudo, proceder à sua adaptação para aplicação neste grupo populacional.

Material e Métodos: Após um pré-teste, a escala foi aplicada a 340 alunos do terceiro ciclo do ensino básico na llha Terceira (Açores, Portugal), com idades entre os 11 e os 19 anos (média = 14,0; desvio-padrão =1,2). Foi analisada a consistência interna e a validade de constructo.

Resultados: $O$ estudo das propriedades psicométricas levou à exclusão de um item. $\mathrm{O}$ alfa de Cronbach $(\alpha=0,876)$ mostrou uma boa consistência interna da escala e a análise fatorial revelou que, tal como a versão original (adultos), a versão para adolescentes apresenta uma estrutura unifatorial.

Discussão: A escala mostrou ser um instrumento de fácil e rápida aplicação em adolescentes. Salienta-se que a sua aplicação deve ser precedida pelo esclarecimento sobre o conceito de alimentos funcionais, de modo a assegurar a adequação das respostas.

Conclusão: Este estudo mostra a adequação do uso da Escala de Atitudes face a Alimentos Funcionais para avaliar a perceção sobre alimentos funcionais em adolescentes, salientando-se a necessidade de utilização da versão adaptada.

Palavras-chave: Açores; Adolescente; Alimento Funcional; Estilo de Vida; Inquéritos e Questionários; Portugal; Psicometria

\section{INTRODUCTION}

Functional foods are those with beneficial physiological effects on health beyond basic nutritional functions, by improving health and well-being and/or reducing the risk of chronic diseases. Their functional compounds must remain in the food and demonstrate their effects in amounts consumed in a normal diet, and these foods should be consumed regularly as part of a healthy diet. ${ }^{1}$

According to the European Commission, ${ }^{2}$ functional foods include: natural foods that have not been changed (e.g. fatty fish with a high amount of polyunsaturated omega-3 fatty acids); foods in which one or more components have been increased, decreased, added or removed (e.g. fruit juice with an increased amount of antioxidants; margarine with added phytosterols; yogurt with reduced fat content); foods in which bioavailability of a component has been modified (e.g. rice that has been genetically modified to increase the bioavailability of iron); or a combination of these.

Functional foods - some of which are specifically directed to youth - are being developed with increasing frequency. For instance, foods supplying the needs of children and adolescents with nutritional deficiencies were among

1. Faculty of Agrarian and Environmental Sciences. University of the Azores. Angra do Heroísmo. Portugal.

2. Faculty of Nutrition and Food Sciences. University of Porto. Porto. Portugal.

3. Faculty of Social and Human Sciences. University of the Azores. Angra do Heroísmo. Portugal.

4. Research Center for Child Studies. University of Minho. Braga. Portugal.

$\bowtie$ Autor correspondente: Leandro Oliveira. leandroliveira.nut@gmail.com

Recebido: 05 de abril de 2018 - Aceite: 23 de outubro de 2018 | Copyright $\odot$ Ordem dos Médicos 2019 
the top ten food trends in $2016 .{ }^{3}$ Accordingly, the functional foods market has enormous potential. However, despite being extremely favorable to the consumers' interests, this fact raises a challenging and complex set of issues for nutritionists, not only due to the various definitions of functional foods, but also because of the difficulty in clearly distinguishing between 'healthy' and 'functional' foods. In addition, it is known that consumers' perception is heavily influenced by marketing, which is able to increase the demand for this type of food, even without scientific evidence concerning its benefits. $^{4,5}$

Parents are a primary authority over the eating habits of their children, ${ }^{6}$ and young people learn about consumption by observing and imitating their parents' behaviors. ${ }^{7}$ It is also known that parents' knowledge about food and nutrition influences young people's eating behavior throughout life. ${ }^{8}$ Several studies have reported low levels of knowledge about functional foods among consumers, ${ }^{9-11}$ including children and adolescents. ${ }^{12,13}$ Moreover, individuals with greater knowledge have more positive attitudes towards such products. $^{9}$

The intention to consume functional foods is also strongly influenced by other consumer-related factors: attitudes, lifestyles, socio-demographic characteristics (such as sex, age or level of education). In addition, it is influenced by factors related to the food itself, such as taste, quality, price, convenience, and its effect on health. ${ }^{14-16}$

Other important factors that positively influence the intention to consume functional foods are the attractiveness of claims for health benefits ${ }^{17}$ and the perception of benefits arising from their consumption. ${ }^{18,19}$ It is worth noting that, according to Goetzke et a ${ }^{20}$ cognitive-emotional well-being is more related to the consumption of functional foods than to the consumption of other kinds of food, and that lower psychological and emotional well-being increase the chance of consumption of functional foods.

According to Markovina et $a^{12}$ the attitudes of young consumers regarding functional foods are mostly affected by health awareness, confidence, and price. Furthermore, the same study showed that the most relevant determinants for buying functional foods (among young consumers) are taste and quality/price ratio.

Considering all these issues, nutritionists play an important role in consumers' education, so that they increase their food literacy, including their knowledge about marketing strategies related to functional foods, and thus become more conscious and informed when choosing these products.

Despite the relevance of assessing attitudes towards functional foods among young consumers, to our knowledge no instrument in Portuguese language is available to perform such assessment. Therefore, the main aim of this study was to analyze the psychometric proprieties of the Attitudes towards Functional Foods Scale (AFFS) in a sample of adolescents. Based on the results of the pre-test and of this analysis we also adapted the scale for its use among this population group.

\section{MATERIAL AND METHODS \\ Instrument}

The AFFS is a tool for assessing the perception and attitudes towards functional foods. It was previously developed and validated for the adult Portuguese population. ${ }^{21}$ This scale was based on the one developed by Urala and Lähteenmäki (2007) ${ }^{19}$ which aimed to assess attitudes towards functional foods among the Finnish population and included 26 items. The AFFS comprises 17 items, mostly selected and adapted from the Urala and Lähteenmäki's scale. Such selection and adaptation were necessary not only for cultural reasons but also because the language needed to be simplified in order to enhance the understanding of the items, considering that previous studies ${ }^{11,13,22}$ reported low levels of knowledge about functional foods among the Portuguese population. For instance, the item "The growing number of functional foods on the market is a bad trend for the future" was not included given consumer's low knowledge regarding the issue, and in the item "Functional foods help to improve my mood", "mood" was replaced with "well-being", since in Portuguese the common use of "well-being" is closer to the original than direct translations for "mood".

At the beginning of the scale, a brief definition of functional foods was provided ("foods that improve health and well-being and/or reduce the risk of certain diseases"), in order to ensure that the concept was as clear as possible for all the participants. The items consist of statements related to: benefits of consuming functional foods (items 1, 3, 4, 9 and 14), reasons why these should be consumed (items 2 , 5,7 and 11), trust (items 6,16 and 17), and safety (items 8 , 10, 13 and 15).

Prior to the main study, a pre-test was carried out, in which the scale was applied to a convenience sample of 10 adolescents attending the $3^{\text {rd }}$ cycle of basic education. This pre-test was intended to ensure that the participants understood the items and instructions. Based on its results, some items were rephrased, in order to facilitate their understanding. Despite these changes, we will continue to refer to this scale as AFFS, in order to make the text easier to read.

The initial version of AFFS included 17 items (whose order of presentation was randomized), answered in a fivepoint Likert-like scale: 1 = "Strongly disagree"; 2 = "Disagree"; 3 = "Neither agree nor disagree"; 4 = "Agree"; and 5 = "strongly agree". An additional response option ("I don't know ") was included, and the value assigned to this option was 3 (the scale's midpoint). Items $2,4,5,6,7,8,11,14$, 15 and 16 were quoted in reverse. The total score, obtained by adding the scores of all items, ranges from 17 to 85 . For each item and total score, higher values correspond to more positive perceptions and attitudes towards functional foods.

\section{Sample and procedures}

All the seven basic education schools of Terceira island (Azores, Portugal) were invited to participate, from which five agreed to participate. Within these five schools, we 
selected, based on scheduling availability and convenience, three classes per grade within the $3^{\text {rd }}$ cycle of basic education (total of 432 potential participants).

The study was approved by the governing bodies of the five schools that agreed to participate, and written informed consent was provided by the parents of all the participants. The informed consent form addressed to the parents included information on the nature of the study, conditions of participation (namely data confidentiality), and how to contact a member of the research team, if needed.

The questionnaires, of direct answer, were filled in a classroom setting by those students who accepted to participate and whose parents had authorized their participation. The distribution of consent forms and all data collection took place between March and June 2015. The project was carried out in accordance with all ethical requirements in the Helsinki Declaration and applicable legislation.

Table 1 - Reliability analysis

\begin{tabular}{|c|c|c|c|c|c|}
\hline \multirow[b]{2}{*}{$\begin{array}{l}\text { Portuguese } \\
\text { (as presented in the questionnaire) }\end{array}$} & \multirow[b]{2}{*}{$\begin{array}{l}\text { English } \\
\text { (back-translated) }\end{array}$} & \multicolumn{2}{|c|}{$\begin{array}{l}\text { All items } \\
\text { (AFFS) }\end{array}$} & \multicolumn{2}{|c|}{$\begin{array}{l}\text { Without item } 13 \\
\text { (AFFSa) }\end{array}$} \\
\hline & & $\begin{array}{l}\text { Corrected } \\
\text { item-total } \\
\text { correlation }\end{array}$ & $\begin{array}{l}\text { Cronbach's } \\
\text { alpha if item } \\
\text { is deleted }\end{array}$ & $\begin{array}{l}\text { Corrected } \\
\text { item-total } \\
\text { correlation }\end{array}$ & $\begin{array}{l}\text { Cronbach's } \\
\text { alpha if item } \\
\text { is deleted }\end{array}$ \\
\hline $\begin{array}{l}\text { 1. Consumir alimentos funcionais é } \\
\text { o mesmo que ter uma alimentação } \\
\text { saudável. }\end{array}$ & $\begin{array}{l}\text { 1. Eating functional foods is the } \\
\text { same as having a healthy diet. }\end{array}$ & 0.444 & 0.861 & 0.452 & 0.872 \\
\hline $\begin{array}{l}\text { 2. Os alimentos funcionais são inúteis } \\
\text { para uma pessoa saudável. }\end{array}$ & $\begin{array}{l}\text { 2. Functional foods are useless for } \\
\text { a healthy person. }\end{array}$ & 0.603 & 0.854 & 0.612 & 0.865 \\
\hline $\begin{array}{l}\text { 3. Os alimentos funcionais podem } \\
\text { reparar os danos causados por uma } \\
\text { alimentação pouco saudável. }\end{array}$ & $\begin{array}{l}\text { 3. Functional foods can repair the } \\
\text { damage caused by an unhealthy } \\
\text { diet. }\end{array}$ & 0.420 & 0.862 & 0.420 & 0.873 \\
\hline $\begin{array}{l}\text { 4. Os alimentos funcionais não têm } \\
\text { um sabor agradável. }\end{array}$ & $\begin{array}{l}\text { 4. Functional foods don't have a } \\
\text { pleasant taste. }\end{array}$ & 0.499 & 0.859 & 0.503 & 0.870 \\
\hline $\begin{array}{l}\text { 5. Os alimentos funcionais são } \\
\text { desnecessários. }\end{array}$ & $\begin{array}{l}\text { 5. Functional foods are } \\
\text { unnecessary. }\end{array}$ & 0.646 & 0.852 & 0.657 & 0.863 \\
\hline $\begin{array}{l}\text { 6. Os anúncios sobre os benefícios } \\
\text { dos alimentos funcionais são falsos. }\end{array}$ & $\begin{array}{l}\text { 6. Commercials on the benefits of } \\
\text { functional foods are false. }\end{array}$ & 0.548 & 0.857 & 0.549 & 0.868 \\
\hline $\begin{array}{l}\text { 7. Os alimentos funcionais são } \\
\text { apenas para idosos, doentes ou } \\
\text { crianças. }\end{array}$ & $\begin{array}{l}\text { 7. Functional foods are only for the } \\
\text { elderly, sick people or children. }\end{array}$ & 0.611 & 0.854 & 0.617 & 0.865 \\
\hline $\begin{array}{l}\text { 8. Os alimentos funcionais podem ter } \\
\text { efeitos indesejáveis. }\end{array}$ & $\begin{array}{l}\text { 8. Functional foods can have } \\
\text { undesirable effects. }\end{array}$ & 0.592 & 0.855 & 0.592 & 0.866 \\
\hline $\begin{array}{l}\text { 9. Os alimentos funcionais são } \\
\text { capazes de melhorar o meu bem- } \\
\text { estar. }\end{array}$ & $\begin{array}{l}\text { 9. Functional foods are able to } \\
\text { improve my well-being. }\end{array}$ & 0.570 & 0.856 & 0.577 & 0.867 \\
\hline $\begin{array}{l}\text { 10. É seguro utilizar alimentos } \\
\text { funcionais. }\end{array}$ & $\begin{array}{l}\text { 10. It is safe to use functional } \\
\text { foods. }\end{array}$ & 0.582 & 0.856 & 0.592 & 0.866 \\
\hline $\begin{array}{l}\text { 11. Os alimentos funcionais são uma } \\
\text { moda que vai passar. }\end{array}$ & $\begin{array}{l}\text { 11. Functional foods are a trend } \\
\text { that will pass. }\end{array}$ & 0.601 & 0.854 & 0.606 & 0.865 \\
\hline $\begin{array}{l}\text { 12. A segurança dos alimentos } \\
\text { funcionais está bem estudada. }\end{array}$ & $\begin{array}{l}\text { 12. The safety of functional foods is } \\
\text { well studied. }\end{array}$ & 0.439 & 0.861 & 0.428 & 0.873 \\
\hline $\begin{array}{l}\text { 13. Os alimentos funcionais em } \\
\text { excesso são prejudiciais. }\end{array}$ & $\begin{array}{l}\text { 13. The excess of functional foods } \\
\text { is harmful. }\end{array}$ & 0.088 & 0.876 & & \\
\hline $\begin{array}{l}\text { 14. Os alimentos funcionais são mais } \\
\text { caros. }\end{array}$ & $\begin{array}{l}\text { 14. Functional foods are more } \\
\text { expensive. }\end{array}$ & 0.430 & 0.862 & 0.436 & 0.873 \\
\hline $\begin{array}{l}\text { 15. Os únicos alimentos funcionais } \\
\text { são os que alegam benefícios de } \\
\text { saúde no rótulo. }\end{array}$ & $\begin{array}{l}\text { 15. The only functional foods are } \\
\text { those whose labels claim health } \\
\text { benefits. }\end{array}$ & 0.429 & 0.862 & 0.423 & 0.873 \\
\hline $\begin{array}{l}\text { 16. Acredito no efeito dos alimentos } \\
\text { funcionais se um médico me } \\
\text { recomendar o produto. }\end{array}$ & $\begin{array}{l}\text { 16. I believe in the effect of } \\
\text { functional foods if a doctor } \\
\text { recommends me the product. }\end{array}$ & 0.484 & 0.860 & 0.483 & 0.872 \\
\hline \multirow[t]{2}{*}{$\begin{array}{l}\text { 17. Os alimentos funcionais têm, de } \\
\text { facto, os benefícios para a saúde que } \\
\text { são anunciados. }\end{array}$} & $\begin{array}{l}\text { 17. Functional foods have, indeed, } \\
\text { the advertised health benefits. }\end{array}$ & 0.379 & 0.864 & 0.372 & 0.875 \\
\hline & Cronbach's alfa coefficient & \multicolumn{2}{|c|}{0.866} & \multicolumn{2}{|c|}{0.876} \\
\hline
\end{tabular}




\section{Statistical analysis}

Statistical analysis was performed with IBM SPSS Statistics, version 23.0 for Windows.

The Mann-Whitney test was used to compare the answers to each item between sexes. Given the absence of significant differences, the following analysis was performed for the entire sample (i.e., not splitted by sex). The internal consistency of the scale was measured using the Cronbach's alpha coefficient, and items with item-total correlations below 0.2 were excluded. ${ }^{23}$ The scale was submitted to factor analysis by principal component extraction method (without rotation). The factor analysis models were validated using the Kaiser-Meyer-Olkin (KMO) sampling adequacy measure and Bartlett's test. The scree plot method ${ }^{24}$ was used to determine the number of components to be retained. The null hypothesis was rejected when the level of critical significance for its rejection $(p)$ was below 0.05 .

\section{RESULTS}

A total of 432 adolescents were invited to participate in the study, $66(15.3 \%)$ of which were not included due to lack of parental consent or to their own refusal. Data from 26 $(7.1 \%)$ of the 366 participants was excluded due to incompleteness of the questionnaire.

We thus analyzed data of 340 students. Of these, $57.4 \%$ $(n=195)$ were females and $42.6 \%(n=145)$ were males. The participants' ages ranged from 11 to 19 years (mean = $14.0, \mathrm{SD}=1.2$ ). Most students were attending the 9th grade $(40.0 \%), 30.6 \%$ the $8^{\text {th }}$ grade and $29.4 \%$ the $7^{\text {th }}$ grade.

\section{Reliability and factor analysis}

Table 1 shows the results of the reliability analysis. Given its low item-total correlation, item 13 was excluded, thus reducing the scale to 16 items. This 16 -item version, which also includes the reformulation of items based on the pretest, was considered a new version of the scale "Attitudes towards Functional Foods Scale - version for adolescents" (AFFSa). The Cronbach's alpha $(\alpha=0.876)$ reveals that the

\section{A}

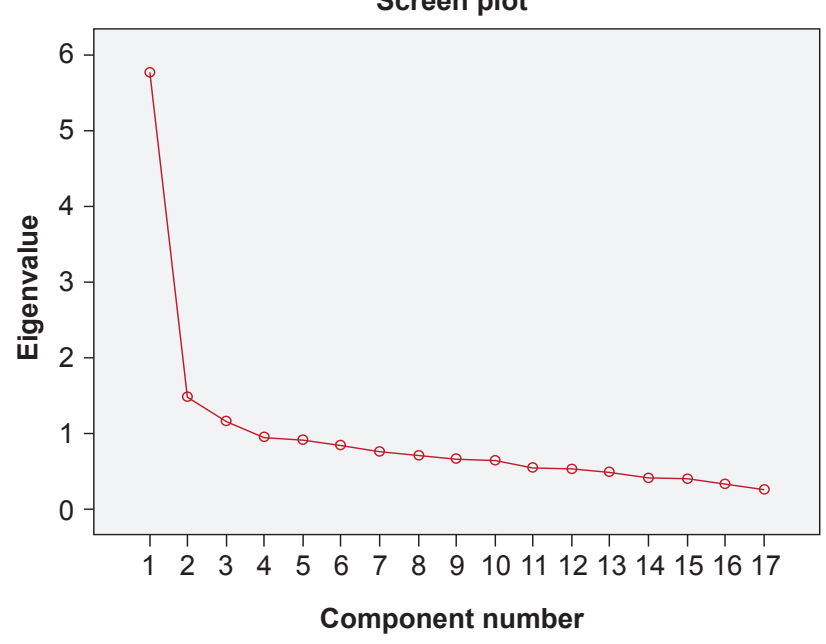

scale has a good internal consistency.

Table 2 presents the results of the factor analysis. Both the KMO and Bartlett's test indicate a good adequacy of the model. Despite the generation of three components with eigenvalues higher than 1, the scree plot analysis (Figure 1) suggested an unifactorial solution, with the latent factor explaining $36.0 \%$ of the total variance. All items presented a positive correlation with this factor.

\section{DISCUSSION}

The AFFSa showed to be an instrument of easy and quick application among adolescents, just like the original version (for adults). ${ }^{21}$ The total time of application of the questionnaire was about 5 minutes and during its application no questions were asked regarding the instructions or the items' meaning. It is worth highlighting that the use of AFFSa should be preceded by a clarification of the concept of functional foods, since, as previously stated, knowledge about this subject among adolescents is low. ${ }^{13}$

The study of the psychometric properties of AFFSa led to the exclusion of one item from the initial version. Despite this change, and as the adults' AFFS, ${ }^{21}$ it presents an unifactorial structure, unlike the scale developed by Urala and Lähteenmäki ${ }^{19}$ for which the authors proposed a tetrafactorial structure.

The AFFSa presented a good internal consistency, and the exploratory factor analysis showed a good correlation between items. The extraction of factors based on the scree plot analysis showed that there was only one latent factor, which explains $36.0 \%$ of the total variance. This value is similar to the one found for the adults' scale (30.4\%). ${ }^{21}$ In the Urala and Lähteenmäki's scale ${ }^{19}$ the four factors explained a somewhat higher variance $(44.0 \%)$, but this proportion was highly distributed through the four factors (from $14.0 \%$ for the $1^{\text {st }}$ factor to $9.0 \%$ for the $4^{\text {th }}$ ).

For future research, it would be important to carry out studies able to generate normative data, taking into account socio-demographic characteristics. Such data might

B

Screen plot

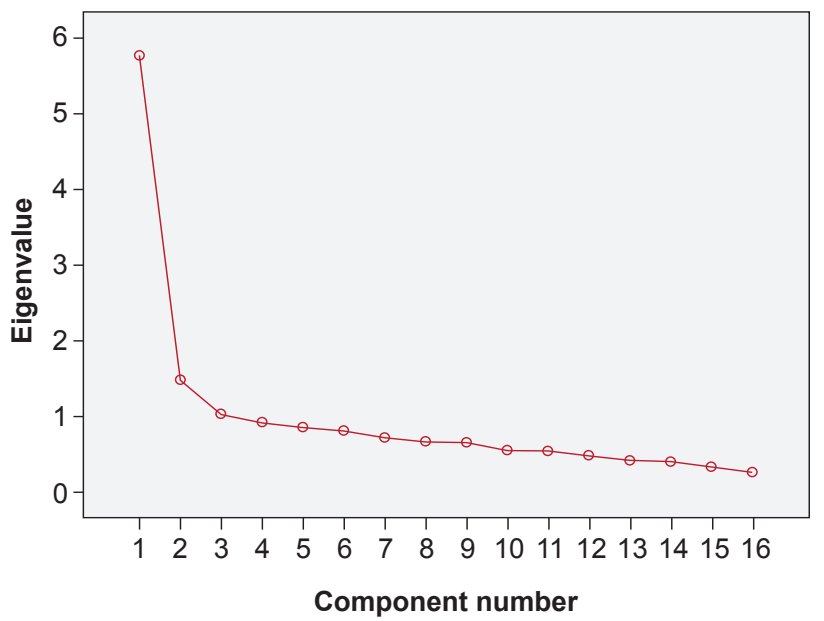

Figure 1 - Scree plots: A - all items (AFFS); B - without item 13 (AFFSa). 
Table 2 - Principal component analysis

\begin{tabular}{|c|c|c|c|c|c|c|c|}
\hline & & & $\begin{array}{l}\text { All items } \\
\text { (AFFS) }\end{array}$ & & & $\begin{array}{l}\text { hout iter } \\
\text { (AFFSa) }\end{array}$ & \\
\hline Kais & er-Meyer-Olkin & & 0.894 & & & 0.896 & \\
\hline Bart & lett $(p)$ & & $<0.001$ & & & $<0.001$ & \\
\hline Com & iponent & C1 & $\mathrm{C} 2$ & C3 & C1 & $\mathrm{C} 2$ & C3 \\
\hline Eige & nvalue & 5.772 & 1.490 & 1.167 & 5.764 & 1.490 & 1.040 \\
\hline Varis & ance (\%) & 33.953 & 8.763 & 6.865 & 36.027 & 9.310 & 6.500 \\
\hline Stat & ements & & & & & & \\
\hline & 1. Eating functional foods is the same as having a healthy diet. & 0.522 & 0.403 & -0.178 & 0.523 & 0.401 & -0.204 \\
\hline & 2. Functional foods are useless for a healthy person. & 0.693 & 0.075 & -0.247 & 0.693 & 0.072 & -0.304 \\
\hline & $\begin{array}{l}\text { 3. Functional foods can repair the damage caused by an } \\
\text { unhealthy diet. }\end{array}$ & 0.491 & 0.386 & -0.011 & 0.491 & 0.387 & -0.079 \\
\hline & 4. Functional foods don't have a pleasant taste. & 0.579 & -0.256 & 0.012 & 0.579 & -0.256 & 0.035 \\
\hline & 5. Functional foods are unnecessary. & 0.733 & -0.110 & -0.297 & 0.735 & -0.114 & -0.410 \\
\hline : & 6. Commercials on the benefits of functional foods are false. & 0.626 & -0.244 & -0.031 & 0.625 & -0.244 & -0.110 \\
\hline : & $\begin{array}{l}\text { 7. Functional foods are only for the elderly, sick people or } \\
\text { children. }\end{array}$ & 0.698 & -0.160 & -0.215 & 0.698 & -0.162 & -0.320 \\
\hline : & 8. Functional foods can have undesirable effects. & 0.667 & -0.386 & 0.054 & 0.666 & -0.385 & 0.074 \\
\hline : (1) & 9. Functional foods are able to improve my well-being. & 0.651 & 0.472 & -0.064 & 0.652 & 0.470 & 0.001 \\
\hline 至: & 10. It is safe to use functional foods. & 0.665 & 0.403 & 0.015 & 0.666 & 0.402 & 0.201 \\
\hline 先 & 11. Functional foods are a trend that will pass. & 0.682 & -0.220 & 0.077 & 0.682 & -0.220 & 0.211 \\
\hline (j) & 12. The safety of functional foods is well studied. & 0.499 & 0.240 & 0.467 & 0.497 & 0.246 & 0.559 \\
\hline & 13. The excess of functional foods is harmful. & 0.096 & -0.025 & 0.751 & & & \\
\hline & 14. Functional foods are more expensive. & 0.507 & -0.368 & 0.055 & 0.508 & -0.369 & 0.279 \\
\hline & $\begin{array}{l}\text { 15. The only functional foods are those whose labels claim } \\
\text { health benefits. }\end{array}$ & 0.482 & -0.303 & 0.262 & 0.481 & -0.300 & 0.315 \\
\hline & $\begin{array}{l}\text { 16. I believe in the effect of functional foods if a doctor } \\
\text { recommends me the product. }\end{array}$ & 0.557 & -0.121 & 0.028 & 0.557 & -0.120 & -0.082 \\
\hline & $\begin{array}{l}\text { 17. Functional foods have, indeed, the advertised health } \\
\text { benefits. }\end{array}$ & 0.439 & 0.356 & 0.268 & 0.437 & 0.359 & 0.173 \\
\hline
\end{tabular}

add value to results obtained by the application of the AFFSa, thus improving and widening its potential use in the development of policies and strategies related to the consumption of functional foods among adolescents.

\section{CONCLUSION}

The AFFSa showed adequate properties for the assessment of adolescents' perception and attitudes towards functional foods. This instrument can be used, for example, to assess the results of both food marketing strategies and food education programs aimed at demystifying misbeliefs related to functional foods, thus promoting food literacy and more informed food choices.

\section{ACKNOWLEDGEMENTS}

We are grateful to the Calouste Gulbenkian Foundation for funding this part of the project "Health-promoting foods in schools - more knowledge, better growth" within the Literacy in Health 2014 contest - "Citizens and Health: improving information, improve decision".

\section{CONFLICTS OF INTEREST}

The authors have no conflicts of interest to declare.

\section{PROTECTION OF HUMANS AND ANIMALS}

The authors declare that all procedures followed the Helsinki Declaration of the World Medical Association. 


\section{DATA CONFIDENTIALITY}

The authors declare having followed the protocols in use at their working center regarding participants' data publication and conidentiality. All procedures followed the Helsinki Declaration of the World Medical Association.

\section{REFERENCES}

1. Scientific concepts of functional foods in Europe: consensus document. Br J Nutr. 1999;81:S1-27.

2. European Commission. Functional foods. Luxembourg: Publications Office of the European Union; 2010.

3. Institute of Food Technologists. Top Ten Functional Food Trends for 2016 2016. [accessed 2017 March 02]. [Available from: http://www. ift.org/Newsroom/News-Releases/2016/April/26/Top-Ten-FunctionalFood-Trends-2016.aspx.

4. McConnon A, Cade J, Pearman A. Stakeholder interactions and the development of functional foods. Public Health Nutr. 2002;5:469-77.

5. Menrad K. Market and marketing of functional food in Europe. J Food Eng. 2003;56:181-88.

6. Preston C. Parental influence upon children's diet: the issue of category. International J Consum Stud. 2010;34:179-82.

7. Birch LL, Fisher JO. Mothers' child-feeding practices influence daughters' eating and weight. Am J Clin Nutr. 2000;71:1054-61.

8. Bruce AS, Lim SL, Smith TR, Cherry JB, Black WR, Davis AM, et al. Apples or candy? Internal and external influences on children's food choices. Appetite. 2015;93:31-4.

9. Armstrong G, Farley H, Gray J, Durkin M. Marketing health-enhancing foods: implications from the dairy sector. Mare Intell Plann. 2005;23:70519.

10. Viana JV, Da Cruz AG, Zoellner SS, Silva R, Batista ALD. Probiotic foods: consumer perception and attitudes. Int J Food Sci Technol. 2008;43:1577-80.

11. Oliveira H. O consumo de alimentos funcionais - atitudes e comportamentos [Dissertação de Mestrado]. Lisboa: Universidade Fernando Pessoa; 2008.

12. Markovina J, Čačić J, Kljusurić J, Kovačić D. Young consumers' perception of functional foods in Croatia. Br Food J. 2011;113:7-16.

13. Oliveira L. Perceção da comunidade educativa sobre os alimentos

\section{FUNDING SOURCES}

This work was funded by the Calouste Gulbenkian Foundation and was part of the project "Health-promoting foods in schools - more knowledge, better growth" within the Literacy in Health 2014 contest - "Citizens and Health: improving information, improve decision".

promotores de saúde e da sua inclusão no plano curricular do $3 .^{\circ}$ ciclo do ensino básico [Dissertação de Mestrado]. Angra do Heroísmo: Universidade dos Açores; 2016.

14. Urala N, Lähteenmäki L. Attitudes behind consumers' willingness to use functional foods. Food Qual Preference. 2004;15:793-803.

15. Badrie N, Reid-Foster S, Benny-Ollivierra C, Roberts $H$. Exercise enthusiasts' perceptions and beliefs of functional foods in Trinidad, West Indiesnull. Nutr Food Sci. 2007;37:345-57.

16. Pappalardo G, Lusk JL. The role of beliefs in purchasing process of functional foods. Food Qual Preference. 2016;53:151-58.

17. van Kleef E, van Trijp HC, Luning P. Functional foods: health claimfood product compatibility and the impact of health claim framing on consumer evaluation. Appetite. 2005;44:299-308.

18. Urala N, Lahteenmaki L. Hedonic ratings and perceived healthiness in experimental functional food choices. Appetite. 2006;47:302-14.

19. Urala N, Lähteenmäki L. Consumers' changing attitudes towards functional foods. Food Qual Preference. 2007;18:1-12.

20. Goetzke B, Nitzko S, Spiller A. Consumption of organic and functional food. A matter of well-being and health? Appetite. 2014;77:96-105.

21. Oliveira L, Poínhos R, Sousa F, Silveira MG. Construção e validação de um questionário para avaliação da perceção sobre alimentos funcionais. Acta Port Nutr. 2016;7:14-7.

22. Ferrão M. Percepção dos consumidores portugueses sobre os alimentos funcionais [Dissertação de Mestrado]. Estoril: Escola Superior de Hotelaria e Turismo do Estoril; 2012.

23. Streiner D, Norman G. Health measurement scales: pratical guide to their development and use. $4^{\text {th }}$ ed. Oxford: Oxford University Press; 1989.

24. Cattell RB. The scree test for the number of factors. Multivariate Behav Res. 1966;1:245-76. 